\title{
MENINGKATKAN MINAT DAN HASIL BELAJAR PESERTA DIDIK DENGAN MENGGUNAKAN MODEL PEMBELAJARAN SNOWBALL THROWING MELALUI TAKSONOMI BLOOM
}

\author{
Zakiyah Anwar $^{1 *}$, Muhamad Ruslan Layn², Fitri Ardyanti ${ }^{3}$ \\ ${ }^{1,2,3}$ Program Studi Pendidikan Matematika Universitas Muhammadiyah Sorong \\ *email: kia.albarru@gmail.com
}

\begin{abstract}
This study aims to determine the interest and learning outcomes of learners can be improved after using the model of learning Snowball Throwing through Bloom Taxonomy. The subjects of this study were students of class VIII H MTs State Model Sorong academic year 2017/2018, which amounted to 33 students with 11 male students and 22 female students. This research is Classroom Action Research. The procedure of implementation of action and implementation in the research location is divided into two cycles. In the first cycle conducted as many as 4 times the meeting, the implementation of action using the Snowball Throwing learning model through Bloom Taxonomy. The second cycle is done action as much as 4 times meeting with the same strategy. The results of this study indicate that interest and learning outcomes mathematics learners class VIII H MTs. State Model Sorong increased. Increase seen from percentage of interest that can be seen from student response and activity of student that is equal to $45,00 \%$ in cycle I and increase become $71,77 \%$ in cycle II. The learning outcomes of learners who achieve the value of KKM in cycle I of $18.18 \%$ increased to $78.79 \%$ in cycle II. Based on the results of this study can be concluded that one way to increase interest and learning outcomes of Mathematics is to use the model of learning Snowball Throwing through Bloom Taxonomy on the learning process.
\end{abstract}

Keyword: Learning Interests, Learning Outcomes, Snowball Throwing Learning Model, Bloom's Taxonomy

\begin{abstract}
ABSTRAK
Penelitian ini bertujuan untuk mengetahui minat dan hasil belajar peserta didik dapatkah meningkat setelah menggunakan model pembelajaran Snowball Throwing melalui Taksonomi Bloom. Subjek penelitian ini adalah peserta didik kelas VIII H MTs. Negeri Model Kota Sorong tahun ajaran 2017/2018, yang berjumlah 33 peserta didik dengan 11 peserta didik laki-laki dan 22 peserta didik perempuan. Penelitian ini adalah Penelitian Tindakan Kelas. Prosedur pelaksanaan tindakan dan implementasi di lokasi penelitian terbagi dalam dua siklus. Pada siklus pertama dilakukan sebanyak 4 kali pertemuan, implementasi tindakan dengan menggunakan model pembelajaran Snowball Throwing melalui Taksonomi Bloom. Siklus kedua dilakukan tindakan sebanyak 4 kali pertemuan dengan strategi yang sama. Hasil penelitian ini menunjukkan bahwa minat dan hasil belajar matematika peserta didik kelas VIII H MTs. Negeri Model Kota Sorong meningkat. Peningkatan dilihat dari persentase minat yang dapat dilihat dari respon peserta didik dan aktivitas peserta didik yaitu sebesar $45,00 \%$ pada siklus I dan meningkat menjadai $71,77 \%$ pada siklus II. Adapun hasil belajar peserta didik yang mencapai nilai KKM pada siklus I sebesar 18,18\% meningkat menjadi 78,79\% pada siklus II. Berdasarkan hasil penelitian ini dapat disimpulkan bahwa salah satu cara untuk meningkatkan minat dan hasil belajar Matematika adalah dengan menggunakan model pembelajaran Snowball Throwing melalui Taksonomi Bloom pada proses pembelajaran.
\end{abstract}

Kata kunci: Minat belajar, Hasil Belajar, Model Pembelajaran Snowball Throwing, Taksonomi Bloom

63 Meningkatkan Minat dan Hasil Belajar 


\section{PENDAHULUAN}

Setiap individu pasti mengalami proses belajar, belajar dapat dilakukan oleh siapapun (anak-anak, remaja, orang tua), dimanapun (di sekolah maupun lingkungan tempat tinggal) dan berlangsung seumur hidup. Dalam pendidikan disekolah belajar merupakan kegiatan pokok yang harus dijalani. Tujuan pendidikan akan tercapai apabila proses belajar atau pembelajaran dalam suatu sekolah dapat berlangsung dengan baik, yaitu proses belajar yang melibatkan peserta didik secara aktif dalam proses pembelajaran. Proses pembelajaran berperan penting dalam usaha meningkatkan hasil belajar.

Hasil belajar merupakan hal yang berhubungan dengan kegiatan belajar. Belajar merupakan proses sedangkan hasil belajar adalah sebagian hasil yang telah dicapai seseorang setelah mengalami proses belajar melalui evaluasi yang dilakukan peserta didik yang dituangkan dalam berbentuk data atau angka maupun dalam pengaplikasian pada kehidupan sehari-hari atas ilmu yang didapatkannya. Sudjana (2009:3) mendefinisikan hasil belajar peserta didik pada hakikatnya adalah perubahan tingkah laku sebagai hasil belajar dalam pengertian yang lebih luas mencakup bidang kognitif, afektif, dan psikomotorik.
Sejalan dengan Purwanto (2009:46)

menyatakan bahwa hasil belajar merupakan perubahan perilaku peserta didik akibat belajar. Perubahan perilaku ini disebabkan karena peserta didik mencapai penguasaan atas sejumlah bahan yang diberikan didalam proses belajar mengajar. Pencapaian itu didasarkan atas tujuan pengajaran yang telah ditetapkan. Dari sisi guru, tindak mengajar diakhiri dengan proses evaluasi hasil belajar. Dari sisi peserta didik, hasil belajar merupakan berakhirnya pengajaran dari puncak proses belajar. Hasil itu dapat berupa perubahan dalam aspek kognitif, afektif maupun psikomotorik. Sejalan dengan itu Kahar, 2017 juga menjelaskan bahwa penilaian hasil belajar sangat bergantung pada tiga ranah pembelajaran yaitu, Afektif, psikomotorik dan Kognitif, sehingga perolehan pengetahuan peserta didik menjadi lebih terperinci.

Hasil belajar merupakan salah satu indikator pencapaian tujuan pembelajaran, tidak lepas dari faktor-faktor yang mempengaruhhi hasil belajar itu sendiri. Menurut Slameto (2010:54), faktor-faktor tersebut secara global dapat diuraikan dalam dua bagian, yaitu internal dan eksternal. Factor internal meliputi inteligensi, motivasi, sikap, minat, bakat, konsentrasi. Faktor eksternal meliputi 
faktor keluarga, faktor sekolah, faktor masyarakat.

Sangat disadari baik oleh guru, peserta didik dan orang tua bahwa dalam belajar di sekolah, intelegensi atau kemampuan intelektual memerankan peranan yang penting, khususnya terhadap tinggi rendahnya hasil belajar peserta didik. Meskipun peranan intelegensi sangat berpengaruh terhadap hasil belajar, perlu diingat adapun beberapa faktor lain pun tetap berpengaruh. Diantara faktor-faktor tersebut adalah minat.

Dalam kegiatan belajar, minat belajar sangat dibutuhkan. Bila seorang peserta didik tidak memiliki minat dan perhatiannya terhadap objek yang dipelajari, maka akan sulit untuk diharapkan peserta didik tersebut dapat mengikuti proses pembelajaran dengan baik dan mendapatkan hasil belajar yang memuaskan. Sebaliknya, apabila peserta didik tersebut mengikuti pembelajaran disertai dengan minat dan perhatiannya tertuju pada objek yang dipelajari, maka hasil yang diperoleh akan jauh lebih baik. Seperti yang dikatakan oleh Slameto (2010:180) minat adalah suatu rasa lebih suka dan rasa keterikatan pada suatu hal atau aktivitas, tanpa ada yang menyuruh.

Karena itu seseorang yang didorong oleh minat dan merasa senang dalam belajar dapat memperoleh hasil belajar yang optimal. Faktanya masih banyak ditemukan kurangnya minat belajar pada peserta didik sehingga hasil belajar yang didapatkan kurang optimal. Di lapangan beberapa masalah yang sering dijumpai peneliti adalah kurangnya konsentrasi pada mata pelajaran, keaktifan di dalam kelas, dan minimnya kehadiran dikarenakan kurangnya minat peserta didik untuk mengikuti proses belajar mengajar.

Oleh karena itu penelitian Kahar, (2017) menyatakan bahwa diperlukan adanya upaya untuk meningkatkan minat peserta didik terhadap pendidikan, salah satunya yaitu dengan menggunakan metode yang dapat menarik minat peserta didik. Dengan metode yang tepat, diharapkan dapat meningkatkan minat belajar peserta didik sehingga tujuan pendidikan dapat tercapai.

Berdasarkan uraian di atas, salah satu model pembelajaran yang tepat untuk diterapkan adalah model pembelajaran Snowball Throwing melaui Taksonomi Bloom untuk mengetahui apakah dengan model tersebut dapat meningkatkan minat dan hasil belajar matematika.

\section{METODE}

Jenis penelitian ini menggunakan Rancangan Penelitian Tindakan Kelas (PTK). Penelitian ini dilaksanakan di sekolah MTs Negeri Model Kota Sorong pada kelas VIII $\mathrm{H}$, yang berjumlah 33 
peserta didik terdiri dari 22 siswi dan 11 peserta didik pada mata pelajaran Matematika tahun ajaran ganjil 2017/2018. Pada penelitian tindakan kelas ini direncanakan terdiri dari 2 siklus. Tiap siklus dilaksanakan dengan pembahasan yang ingin dicapai.

\section{Siklus 1}

\section{Tahap 1 : Perencanaan}

a. Membuat tujuan pembelajaran

b. Menyiapkan sumber belajar dari buku dan lembar kerja peserta didik yang disiapkan guru.

c. Menentukan pokok bahasan

d. Membuat lembar observasi untuk melihat kondisi belajar mengajar peserta didik dikelas ketika diajarkan dengan model pembelajaran Snowball Throwing melalui Taksonomi Bloom.

e. Membuat lembar evaluasi untuk melihat minat belajar peserta didik dengan menggunakan model pembelajaran Snowball Throwing melalui Taksonomi Bloom.

\section{Tahap 2 : Pelaksanaan Tindakan}

a. Pembukaan

b. Guru menyiapkan topik materi dan tujuan yang ingin dicapai

c. Guru mempersiapkan materi yang akan diajarkan. membentuk kelompok kelompok dan memanggil ketua kelompok untuk menjelaskan materi yang diberikan.

d. Masing-masing ketua kelompok kembali ke kelompoknya masingmasing, kemudian menjelaskan materi yang disampaikan oleh guru kepada temannya.

e. Kemudian peserta didik diberikan sebuah LKS untuk kemudian membuat pertanyaan terkait materi yang diajarkan.

f. Selanjutnya kertas yang dibuat seperti bola dan dilempar dari satu peserta didik ke peserta didik lain selama kurang lebih 5 menit.

g. Kemudian peserta didik mendapat sebuah bola dengan satu pertanyaan kepada peserta didik untuk menjawab pertanyaan yang tertulis dalam kertas berbentuk bola tersebut secara bergantian.

h. Evaluasi

i. Penutup.

\section{Tahap 3: Observasi dan Evaluasi}

Observasi dilakukan pada saat proses belajar mengajar (PMB) berlangsung. Dengan mencatat semua kegiatan, perubahan dan respon peserta didik selama mengikuti pembelajaran yang peneliti lakukan dengan model pembelajaran Snowball Throwing melalui Taksonomi Bloom. Serta melakukan evaluasi guna mengetahui kemampuan 
peserta didik dalam menemukan solusi dari permasalahan yang diberikan guru.

\section{Tahap 4: Refleksi}

Pada tahap ini hasil yang diperoleh dalam observasi dan evaluasi dikumpulkan dan dianalisis. Kemudian dari hasil tersebut akan dilihat apakah memenuhi target yang ditetapkan pada indikator kerja. Jika belum maka peneliti akan dilanjutkan pada siklus berikutnya dengan memperbaiki kelemahan dan kekurangan pada siklus pertama.

\section{Siklus II}

Langkah-langkah yang dilakukan pada siklus II relatif sama dengan perencanaan dan pelaksanaan dalam siklus I dengan mengadakan beberapa perubahan dan perbaikan serta penambahan sesuai dengan kenyataan yang didapatkan dilapangan.

\section{Teknik dan Instrumen Pengumpulan Data}

Adapun teknik yang digunakan dalam penelitian ini adalah angket respon, observasi dan tes.

\section{Teknik Analisis Data}

Data yang terkumpul dianalisis dengan cara kuantitatif. Data tentang hasil tes, angket respon dan observasi dianalisa secara kuantitatif dengan menggunakan statistik deskriptif kualitatif yaitu statistik yang digunakan untuk mendeskripsikan atau menggambarkan objek yang telah diteliti sebagaimana adanya, penyajian data dalam bentuk ststistik deskriptif. Tes di lakukan menggunakan observasi, angket dan soal yang dibuat oleh peneliti sebanyak 2 kali tes, tes ini dilakukan untuk mengetahui perbandingan respon minat dan hasil belajar pada tes pertama dan tes kedua untuk mengetahui kemampuan hasil belajar peserta didik.

1. Data Angket Respon Peserta didik

Dalam menentukan respon peserta didik dengan menggunakan model pembelajaran Snowball Throwing melalui Taksonomi Bloom digunakan rumus sebagai berikut:

$$
\operatorname{Pr}=\frac{\sum R_{S}}{\sum S} \times 100 \%
$$

Sugiyono (2015 : 95)

Keterangan :

Pr : Presentase banyak peserta didik yang memberikan respon terhadap kategori tertentu yang ditanyakan dalam angket

$\sum \mathrm{R}_{\mathrm{s}}$ : Banyak peserta didik yang memberi respon terhadap kategori tertentu yang ditanyakan dalam angket

$\sum \mathrm{S} \quad$ : Seluruh peserta didik 
Tabel 1 Kriteria Interpretasi Skor Respon Peserta Didik

\begin{tabular}{cc}
\hline NILAI & KRITERIA \\
\hline $90-100$ & Sangat Baik \\
$80-89$ & Baik \\
$70-79$ & Cukup \\
$60-69$ & Rendah \\
$0-59$ & Kurang \\
\hline
\end{tabular}

Khabibah, dkk: (2016:765)

2. Data Hasil Observasi

Data hasil pengamatan aktivitas peserta didik dalam proses belajar mengajar melalui lembar observasi.melalui instrument lembar observasi anak didik dianalisis dengan menggunakan presentase. Presentase pengamatan aktivitas yaitu jumlah soal yang dijawab benar dibagi jumlah butir soal dikali $100 \%$.

Indikator aktifitas peserta didik yaitu, melihat minat peserta didik dari psikomotorik serta afektitfitas peserta didik. Adapun indikator minat dapat dikenali melalui proses pembelajaran:

1. Perhatian peserta didik terhadap guru

2. Peserta didik aktif didalam kelompok

3. Kemampuan peserta didik mengemukakan pendapat

4. Kemampuan peserta didik memanfaatkan waktu
5. Kemampuan peserta didik menarik kesimpulan

3. Data Hasil Belajar Peserta didik Untuk mengetahui hasil belajar peserta didik, peneliti mengambil data dari daftar nilai postest. Kriteria yang digunakan untuk menentukan pencapaian hasil belajar dalam penelitian ini yaitu dengan skala lima sebagai berikut:

Tabel 2 Kategori Skala Lima

\begin{tabular}{cc}
\hline $\begin{array}{c}\text { Rentang Total } \\
\text { Skor }\end{array}$ & Kategori \\
\hline $0 \%-20 \%$ & Tidak Baik \\
$21 \%-40 \%$ & Kurang Baik \\
$41 \%-60 \%$ & Cukup Baik \\
$61 \%-80 \%$ & Baik \\
$81 \%-100 \%$ & Sangat Baik \\
\hline
\end{tabular}

\begin{abstract}
Analisis ketuntasan hasil belajar dapat dihitung dengan menggunakan rumus:
\end{abstract}

$$
\begin{aligned}
& \text { skor diperoleh } \\
& \text { Persentase }=\frac{(\text { jumlah siswa yang nilai diatas KKM) }}{\text { skor maksimal }} \times 100 \%
\end{aligned}
$$

\section{Indikator Keberhasilan}

Penelitian ini dikatakan berhasil atau peserta didik dinyatakan mengalami peningkatan hasil belajar matematika setelah melihat hasil tes yang memenuhi indikator sebagai berikut : 
1. Nilai peserta didik mencapai Kriteria Ketuntasan Minimal (KKM) yang ditentukan sekolah yaitu 73

2. Minimal $70 \%$ dari jumlah peserta didik memperoleh nilai $\geq 73$. Dengan demikian apabila indikator telah tercapai, maka siklus akan dihentikan.

\section{HASIL DAN PEMBAHASAN}

Penelitian ini dilaksanakan di Madrasah Tsanawiyah Negeri Model Kota Sorong yang bertempat di Jl. Basuki Rahmat No. 40 Sorong Papua Barat. Penelitian ini merupakan penelitian tindakan kelas dengan mengambil sampel pada peserta didik kelas VIII $\mathrm{H}$ yang berjumlah 33 peserta didik dengan menggunakan model pembelajaran Snowball Throwing melalui Taksonomi Bloom pada proses pembelajaran yang berlangsung selama 2 siklus. Analisis dilakukan untuk mendeskripsikan hasil dari masing-masing siklus penelitian. Berdasarkan jenis data yang dikumpulkan, maka dapat dijelaskan sebagai berikut:

\section{Hasil Respon Peserta didik}

Angket respon diberikan kepada peserta didik pada pertemuan akhir (pertemuan ke-10) yaitu setelah pemberian postets siklus II. Seperti pada gambar 1 berikut:

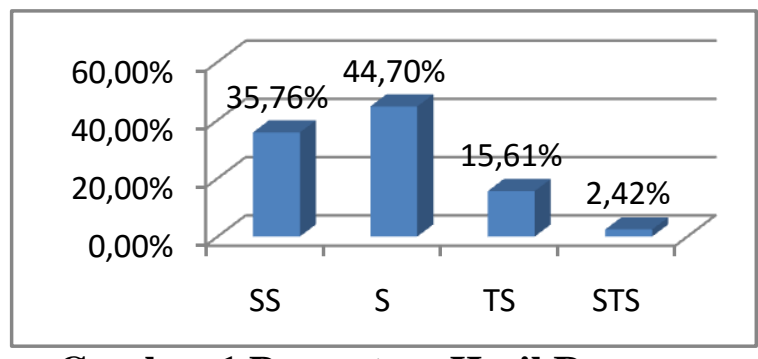

\section{Gambar 1 Persentase Hasil Respon}

\section{Peserta didik}

Dari gambar diatas menunjukkan bahwa angket respon yang diisi 33 peserta didik kelas VIII $\mathrm{H}$ yang berisi kalimat pernyataan positif terhadap proses pembelajaran menggunakan model pembelajaran Snowball Throwing melalui Taksonomi Bloom menghasilkan 35,76\% sangat setuju, 44,70\% setuju, $15,61 \%$ tidak setuju dan 2,42\% sangat tidak setuju.

\section{Hasil Observasi}

a. Hasil Observasi Siklus I

Pada tahap siklus I proses belajar mengajar yang diikuti 33 peserta didik dalam kelas tersebut berlangsung sebanyak 4 kali pertemuan, peneliti melakukan pengamatan secara langsung mengenai minat yang ditunjukan oleh peserta didik terhadap pelajaran Matematika pada tiap pertemuannya. Adapun indikator-indikator yang diamati seperti terlihat pada gambar. 


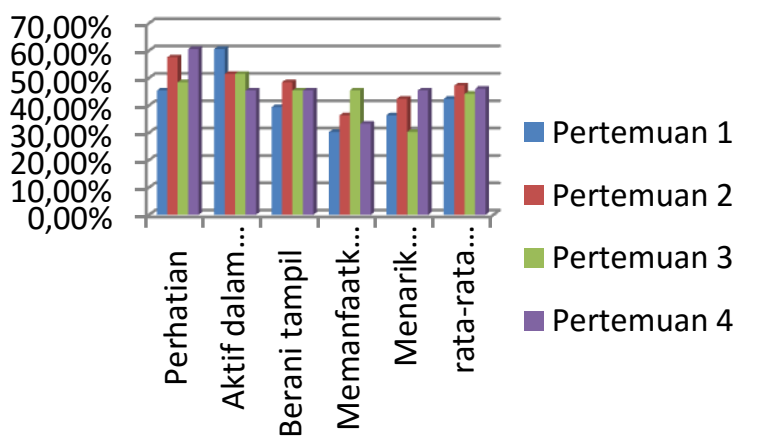

Gambar 2 Hasil Observasi Siklus I

Berdasarkan gambar di atas, Persentase Hasil Observasi Siklus I dengan rata-rata aktifitas sebagai berikut, pada pertemuan pertama peserta didik $42,42 \%$, pertemuan kedua $47,27 \%$, pertemuan ketiga 44,24\%, pertemuan keempat 46, 06\%, dapat dilihat hasil observasi aktivitas peserta didik menunjukan belum ada ketertarikan minat dikarenakan dari data yang didapat masih rendah serta mengalami naik turun persentase aktifitas peserta didik.

b. Hasil Observasi Siklus II

Pada siklus II peneliti masih mengamati aktivitas peserta didik dan didapatkan data pada gambar dibawah ini:

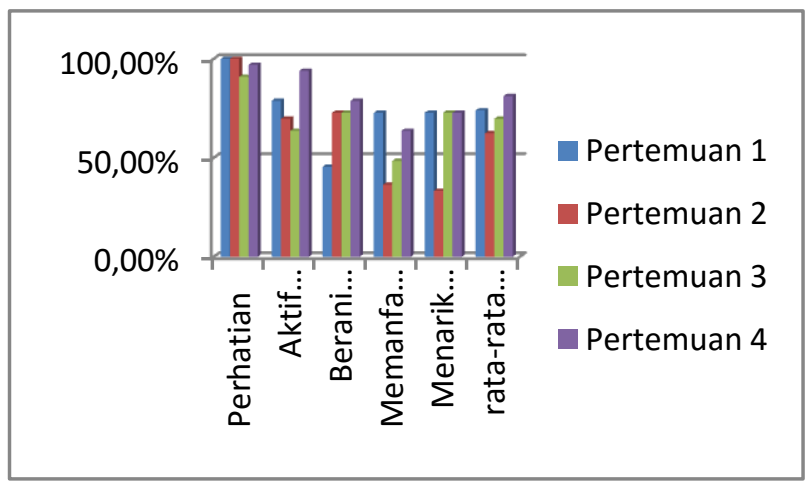

Gambar 3 Hasil Observasi Siklus II
Berdasarkan gambar diatas, Persentase Hasil Observasi Siklus II, dapat dilihat adanya perubahan aktivitas peserta didik pada siklus I dan siklus II. Pada pertemuan pertama peserta didik $73,93 \%$, pertemuan kedua $62,42 \%$, pertemuan ketiga 69,70\%, pertemuan keempat $81,21 \%$, dapat dilihat hasil observasi aktivitas peserta didik menunjukan ketertarikan minat pada kegiatan belajar mengajar khususnya pada pelajaran Matematika dikarenakan dari data yang didapat persentase aktifitas peserta didik meningkat.

\section{Hasil Belajar}

a. Hasil Belajar Siklus I

Analisis skor hasil tes siklus I dari hasil belajar matematika kelas VIII H MTs. Negeri Model Kota Sorong terhadap pokok bahasan Sistem Persamaan Linier Dua Variabel dengan menggunakan model pembelajaran Snowball Throwing melalui Taksonomi Bloom terangkum dalam table berikut:

Tabel 3 Statistik Nilai Tes Hasil Siklus I

\begin{tabular}{ll}
\hline \multicolumn{1}{c}{ Statistik } & Nilai Statistik \\
\hline Subjek & 33 \\
Nilai ideal & 100 \\
Nilai tertinggi & 91 \\
Nilai terendah & 22 \\
Rentang nilai & 69 \\
Nilai rata-rata & 51,35 \\
Standar deviasi & 19,44 \\
\hline
\end{tabular}


Tabel di atas menunjukkan bahwa nilai rata-rata hasil belajar matematika yang telah dicapai peserta didik setelah diadakan perbaikan pembelajaran dengan model pembelajaran Snowball Throwing melalui Taksonomi Bloom 51,35 dengan standar deviasi 19,44. Nilai tertinggi yang diperoleh peserta didik pada siklus I ini adalah 91 dari skor ideal yang mungkin dicapai yaitu 100, sedangkan nilai terendah adalah 22 dari nilai minimum yang mungkin di capai yaitu 0 .

jika nilai peserta didik dikelompokkan ke dalam lima kategori maka diperoleh distribusi frekuensi nilai seperti pada tabel di bawah ini:

Tabel 4 Distribusi Nilai Tes Hasil

Belajar Siklus I

\begin{tabular}{lllr}
\hline Nilai & Kategori & $\mathbf{f}$ & \multicolumn{1}{c}{$\%$} \\
$0-59$ & Sangat Rendah & 23 & $69.70 \%$ \\
$60-69$ & Rendah & 3 & $9.09 \%$ \\
$70-79$ & Sedang & 5 & $15.15 \%$ \\
$80-89$ & Tinggi & 1 & $3.03 \%$ \\
$90-100$ & Sangat Tinggi & 1 & $3.03 \%$ \\
Jumlah & & 33 & $100 \%$ \\
\hline
\end{tabular}

Data di atas menunjukkan bahwa, setelah diterapkan model pembelajaran Snowball Throwing melalui Taksonomi Bloom pada siklus I, 23 peserta didik $(69,7 \%)$ yang memiliki nilai matematika berada dalam kategori sangat rendah, 3 peserta didik $(9,1 \%)$ berada dalam kategori rendah, 5 peserta didik $(15,2 \%)$ berada dalam kategori sedang, 1 peserta didik (3\%) berada dalam kategori tinggi, dan 1 peserta didik (3\%) berada dalam kategori sangat tinggi. Kemudian persentase ketuntasan hasil belajar matematika peserta didik setelah menerapkan metode pembelajaran Snowball Throwing melalui Taksonomi Bloom pada siklus I dapat dilihat pada tabel berikut ini:

Tabel 5 Deskripsi Ketuntasan Belajar Peserta didik Siklus I

\begin{tabular}{lllr}
\hline Nilai & Kategori & Frekuensi & Presentase \\
\hline $00-72$ & Tidak Tuntas & 27 & $81.82 \%$ \\
$73-100$ & Tuntas & 6 & $18.18 \%$
\end{tabular}

Dari data di atas, nampak bahwa jumlah peserta didik yang tuntas sebanyak 6 peserta didik $(18,2 \%)$ dan yang tidak tuntas belajar sebanyak 27 peserta didik (18,2\%). Hal ini menunjukkan bahwa pada siklus I masih perlu adanya perbaikan lagi sehingga peneliti melanjutkan kegiatan pembelajaran pada siklus II.

b. Hasil Tes Siklus II

Analisis secara kuantitatif hasil belajar peserta didik berdasarkan hasil siklus II peserta didik kelas VIII H MTs. Negeri Model Kota Sorong dapat dilihat pada tabel berikut: 
Tabel 6 Statistik Nilai Tes Hasil Siklus

II

\begin{tabular}{ll}
\hline Statistik & Nilai Statistik \\
\hline Subjek & 33 \\
Nilai ideal & 100 \\
Nilai tertinggi & 90 \\
Nilai terendah & 43 \\
Rentang nilai & 47 \\
Nilai rata-rata & 73,32 \\
Standar deviasi & 10,66 \\
\hline
\end{tabular}

Berdasarkan tabel di atas, setelah diadakan tindakan lanjutan menunjukkan bahwa nilai rata-rata hasil belajar matematika peserta didik adalah 73,32 dengan standar deviasi 10,66. Nilai tertinggi yang diperoleh peserta didik pada siklus II ini adalah 90 dari nilai ideal yang mungkin di capai yaitu 100, sedangkan nilai terendah adalah 43 dari nilai minimum yang mungkin dicapai yaitu 0 .

jika nilai peserta didik dikelompokkan ke dalam lima kategori maka diperoleh distribusi frekuensi nilai seperti pada tabel di bawah ini:
Tabel 7 Distribusi Nilai Tes Hasil

Belajar Siklus II

\begin{tabular}{llll}
\hline Nilai & Kategori & f & \% \\
\hline $0-59$ & $\begin{array}{l}\text { Sangat } \\
\text { Rendah }\end{array}$ & 7 & $21.21 \%$ \\
$60-69$ & Rendah & 0 & $0.00 \%$ \\
$70-79$ & Sedang & 19 & $57.58 \%$ \\
$80-89$ & Tinggi & 6 & $18.18 \%$ \\
$90-$ & Sangat & 1 & $3.03 \%$ \\
100 & Tinggi & & $100 \%$ \\
\hline Jumlah & & 33 & \\
\hline
\end{tabular}

Data di atas menunjukkan bahwa, setelah diterapkan metode pembelajaran Snowball Throwing melalui Taksonomi Bloom pada siklus II, 7 peserta didik $(21,2 \%)$ yang memiliki nilai matematika berada dalam kategori sangat rendah, 0 peserta didik $(0 \%)$ berada dalam kategori rendah, 19 peserta didik $(57,6 \%)$ berada dalam kategori sedang, 6 peserta didik $(18,2 \%)$ berada dalam kategori tinggi, dan 1 peserta didik (3\%) berada dalam kategori sangat tinggi. Kemudian persentase ketuntasan hasil belajar matematika peserta didik setelah penerapan model pembelajaran Snowball Throwing melalui Taksonomi Bloom pada siklus II dapat dilihat pada tabel berikut ini: 
Tabel 8. Deskripsi Ketuntasan Belajar Peserta didik Siklus II

\begin{tabular}{llll}
\hline Nilai & Kategori & Frekuensi & Presentase \\
\hline $00-72$ & Tidak Tuntas & 7 & $21,21 \%$ \\
$73-100$ & Tuntas & 26 & $78,79 \%$ \\
\hline
\end{tabular}

Dari data di atas dapat dilihat adanya kenaikan peserta didik yang tuntas dalam belajar, yang pada siklus I sebanyak 6 peserta didik bertambah menjadi 26 peserta didik pada siklus II. Sementara di bawah ini adalah grafik peningkatan nilai tes peserta didik siklus I dan siklus II, sebagai berikut:

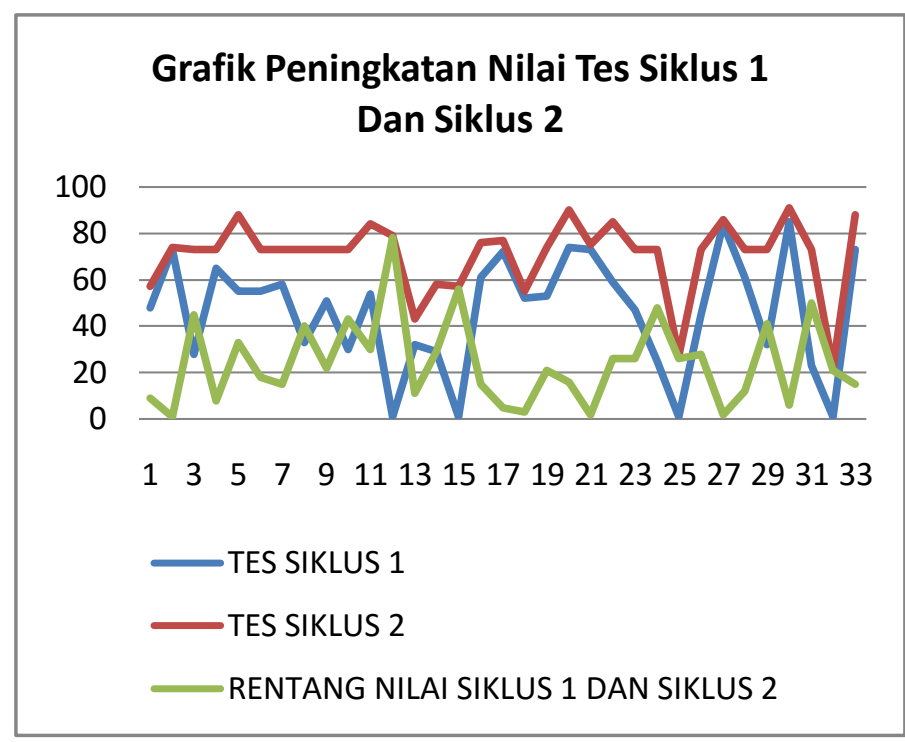

Gambar 4 Grafik Peningkatan Nilai Tes Siklus I dan II

Berdasarkan gambar diatas dapat dilihat adanya rentang nilai tes siklus I dan siklus II terhadap peserta didik kelas VIII H MTs. Negeri Model Kota Sorong.dan dapat dilihat pada grafik diatas menunjukkan adanya peningkatan hasil belajar peserta didik dari tes siklus I sampai siklus II.

\section{PEMBAHASAN}

Hasil penelitian dengan menggunakan model pembelajaran Snowball Throwing melalui Taksonomi Bloom menunjukan adanya penigkatan terhadap minat dan hasil belajar peserta didik. Peningkatan minat peserta didik dapat ditinjau dari hasil data respon peserta didik dan hasil observasi aktivitas peserta didik sedangkan hasil belajar dapat dilihat dari hasil tes yang diberikan peneliti diakhir siklus.

Angket respon yang digunakan untuk melihat minat peserta didik yang diisi 33 peserta didik dari kelas VIII H yang berisi kalimat pernyataan positif terhadap proses pembelajaran menggunakan model pembelajaran Snowball Throwing melalui Taksonomi Bloom menghasilkan $35,76 \%$ sangat setuju, 44,70\% setuju, 15,61\% tidak setuju dan $2,42 \%$ sangat tidak setuju. Selain data dari respon peserta didik untuk melihat minat peserta didik peneliti didukung dengan data yang diperoleh yaitu dari data hasil observasi aktivitas peserta didik. Hal ini sejalan dengan penelitian khoiri et.al (2017) menunjukan bahwa minat peserta didik sangat besar pengaruhnya terhadap prestasi belajar yang didapatkan. persentase hasil observasi pada rata-rata 
siklus I dan siklus II, menunjukan adanya peningkatan minat belajar peserta didik yang ditunjukan oleh aktivitas peserta didik dengan indikator-indikator yang telah ditentukan sebelumnya.

Berdasarkan hasil analisis data yang telah dijelaskan di atas, maka secara deskriptif hasil penelitian tindakan terlihat adanya peningkatan hasil belajar Matematika peserta didik kelas VIII H MTs. Negeri Model Kota Sorong dengan menggunakan model pembelajaran Snowball Throwing melalui Taksonomi Bloom. Dengan perolehan untuk siklus I menunjukkan hasil belajar matematika peserta didik memperoleh 27 (81,82\%) peserta didik tidak tuntas dan $6(18,18 \%)$ peserta didik tuntas mencapai nilai KKM.

Sedangkan hasil analisis untuk siklus II menunjukan hasil belajar matematika peserta didik kelas VIII $\mathrm{H}$ MTs. Negeri Model Kota Sorong memperoleh $7(21,21 \%)$ peserta didik tidak tuntas dan $26(78,79 \%)$ peserta didik tuntas mencapai nilai KKM. Menganalisa hasil tersebut dijelaskan dalam penelitian Kahar, 2017 menyatakan bahwa metode atau model yang diterapkan di kelas sangat berpengaruh terhadap hasil belajar dan kemampuan berpikir kritis peserta didik, selain itu Kahar, 2017 menjelaskan bahwa perangkat dalam pembelajaran perlu di rancang sedemikian rupa guna meningkatkan pemahaman peserta didik pada materi yang diajarkan, sehingga hasil belajar yang di dapatkan menjadi lebih baik.

Berdasarkan hal tersebut, maka jelas bahwa hasil belajar matematika pada siklus II lebih meningkat dibandingkan siklus I, dan memenuhi syarat nilai KKM yang telah ditentukan dari pihak sekolah.

\section{Refleksi Pembelajaran}

a. Siklus I

Pada siklus I guru menemukan kendala yaitu beberapa peserta didik belum dapat diajak bekerjasama, dan memenegement waktu pembelajaran. Adapun peserta didik yang pasif serta malas tau akan kehadiran guru didalam kelas, serta peserta didik belum dapat memaksimalkan kegiatan belajar dengan model pembelajaran yang diterapkan. Suasana gaduh yang ditimbulkan dari penerapan model pembelajaran tersebut membuat guru pada awal-awal pertemuan sangat kelelahan menghadapi peserta didik tersebut. Ditemukan juga pada siklus I beberapa peserta didik banyak yang tidak hadir dengan keterangan sakit bahkan alpha. Hal tersebut dapat berimbas pada hasil belajar mereka yang dapat dilihat dari data yang sudah di jelaskan banyak peserta didik yang tidak tuntas mencapai nilai KKM. Dan menurut pengamatan hal tersebut sebanding dengan minat peserta 
didik yang dapat dilihat dari aktivitas peserta didik.

b. Siklus II

Pada siklus II tentunya guru dan peserta didik mulai dapat menyesuaikan dengan model pembelajaran yang diterapkan. Kehadiran peserta didik pun mulai meningkat persentasenya, aktivitas peserta didik pun meningkat dari pengamatan guru, peserta didik mulai lebih aktif, dapat diajak bekerjasama, berani tampil di depan tanpa rasa malu lagi,serta bertanya, bahkan tidak memungkiri peserta didik datang bertanya diluar dari materi yang dibawakan. Hasil tes yang di dapat pada siklus II jauh meningkat dan mencapai nilai KKM yang diharapkan.

\section{SIMPULAN}

Berdasarkan hasil penelitian yang berlangsung selama dua siklus, dapat ditarik kesimpulan bahwa dengan menggunakan model pembelajaran Snowball Throwing melalui Taksonomi Bloom terjadi peningkatan persentase minat yang dapat dilihat dari respon peserta didik dengan pernyataan positif menghasilkan $35,76 \%$ sangat setuju, $44,70 \%$ setuju, $15,61 \%$ tidak setuju, $2,42 \%$ sangat tidak setuju, dan juga aktivitas peserta didik yaitu sebesar $45,00 \%$ pada siklus I dan meningkat menjadai $71,77 \%$ pada siklus II. Adapun terjadi peningkatan pada jumlah peserta didik yang tuntas belajar, yaitu pada Siklus I presentase peserta didik yang tuntas belajar sebesar $18,18 \%$ dan yang tidak tuntas belajar sebesar $81,82 \%$. Sedangkan pada Siklus II, presentase peserta didik yang tuntas belajar sebesar $78,79 \%$ dan yang tidak tuntas belajar sebesar $21,21 \%$. Peningkatan hasil belajar juga dapat dilihat dari skor rata-rata Siklus I sebesar 51,35 dan Siklus II meningkat menjadi sebesar 73,32. Hal ini menunjukan bahwa terdapat peningkatan yang signifikan antara minat dan hasil belajar dengan menggunakan model pembelajaran Snowball Throwing melalui Taksonomi Bloom.

\section{DAFTAR PUSTAKA}

Kahar, M. S. (2018). Assesmen Portofolio untuk Meningkatkan Hasil Belajar Fisika. Jurnal Edukasi Matematika dan Sains, 5(2), 53-61.

Kahar, M. S. (2017). Pengembangan Perangkat Pembelajaran Fisika Dengan Menggunakan Model Pembelajaran Kooperatif Tipe STAD. JIPF (Jurnal Ilmu Pendidikan Fisika), 2(2), 42-49.

Kahar, M. S. (2017). Analisis Kemampuan Berpikir Matematis Siswa SMA kota Sorong terhadap Butir Soal dengan Graded Response Model. Tadris: Jurnal Keguruan dan Ilmu Tarbiyah, 2(1), 11-18. 
Kahar, M. S. (2017). Analisis Minat Belajar Mahasiswa Terhadap Penggunaan Alat Peraga Neraca Cavendish. SEJ (Science Education Journal), 1(2), 73-83.

Khoiri, A., Nasihah, U., \& Kahar, M. S. (2017). Analisis Prestasi Belajar Fisika Berpendekatan SETS di Tinjau dari Motivasi Berprestasi. Jurnal Riset dan Kajian Pendidikan Fisika, 4(2), 8389.

Khabibah, EN. Kuswanti,N. Suparno,G (2014). Validitas Teoritis Modul Berbasis Guided Dicovery Pada Materi Respiratory System. Universitas Negeri Surabaya.http://ejournal.unesa.ac.id ?indeks.php/bioedu

Purwanto. 2009. Evaluasi Hasil Belajar, Yogyakarta: Pustaka Pelajar.

Slameto. 2010. Belajar dan Faktor-Faktor yang Mempengaruhinya. Jakarta: Rineka Cipta.

Sudjana, Nana. 2009. Penilaian Hasil Proses Belajar Mengajar. Bandung: PT Remaja Rosdakarya.

Sugiarta, K. 2012. Penerapan Model Pemelajaran Kooperatif Tipe Scramble untuk Meningkatkan Aktivitas dan Hasil Belajar Kelas XI SMA Saraswati Singaraja pada Mata Pelajaran Ekonomi. Pdf. (diakses 3 juli 2017).

Sugiyono.(2015). MetodePenelitian Kuantitatif Kualitatif \& RND. Bandung : Alfabeta 